Г.Возняк, Л. Беновська // Вісник Львів. ун-ту. Серія екон. - 2009. - Вип. 41. - С. 115-123.

3. Гуменюк Ю.П. Людський капітал та вплив його глобального переливу на соціальноекономічний розвиток / Ю.П.Гуменюк// Вісник Національного університету «Львівська політехніка». Менеджмент та підприємництво в Україні: етапи становлення i проблеми розвитку. -2010 .- № 682.- С.279-270.

4. Економічна енциклопедія: У 3-х т./ Редкол.: С.В.Мочерний (відп. ред.) та ін.- К.: Видавничий центр «Академія», 2000.- Т. 2.- С. 216.

5. Кендюхов О.В. Організаційноекономічний механізм управління інтелектуальним капіталом підприємства : автореф. дис. на здобуття наук. ступеня д-ра екон. наук: спец. 08.00.04 «Економіка та управління підприємствами (переробна промисловість)» / О.В. Кендюхов. - Донецьк, 2007. - $31 \mathrm{c}$.

6. Колот А.М. Інноваційна праця та інтелектуальний капітал у системі факторів формування економіки знань / А.М.Колот // Економічна теорія. -2007. - № 2. - С. 3 -13.

7. Коюда В.А. Интеллектуальный потенциал в формировании интеллектуального капитала предприятия: материалы I Международной конференции «Роль и значение интеллектуальной собственности в инновационном развитии экономики» [Електронний ресурс] / В.А. Коюда, В. В. Воликов. 4- 6 ноября 2009г., г. Хмельницкий, Украина - Режим доступу: www.icsti.su/uhloaded/20103/intel prop/5pdf.

8. Лукичёва Л. И. Управление интеллектуальным капиталом / Л. И. Лукичёва. - 2-е изд., стер. - М.: Омега-Л, 2008. - 552 с.

9. Стюарт Т. Интеллектуальный капитал. Новый источник богатства организаций / Т. Стюарт / пер. с англ. В. Ноздриной. - М. : Поколение, 2007. - 368 с.

10. Федулова Л. I. Концепція інтелектуального капіталу в системі економіки знань / Л. І. Федулова // Проблеми науки: Міжгалузевий науково-технічний журнал. 2006. - № 3. - С. 34 - 38 .

11. Черепніна О.I. Розвиток видів капіталу і підвищення конкурентоспроможності національної економіки/ О.І.Черепніна // Теоретичні та прикладні питання економіки. 2011.- Вип.26.- С.168-172.

Рецензент д.е.н., професор ХНУБА Чупир О.М. Експерт редакційної колеаії к.е.н., доцент УкрДУЗТ Зубенко В.О.

УДК: 339.138: 658.8

\title{
МАРКЕТИНГОВІ СТРАТЕГІЇ В АНТИКРИЗОВОМУ УПРАВЛІННІ ПІДПРИСМСТВОМ
}

\author{
Терещенко Д.А., к.держ.упр., доцент, \\ Тітова Н.О., студентка (ХНУБА)
}

\begin{abstract}
У статті досліджується сучасна проблематика маркетингу як філософії, стратегії $i$ тактики антикризового управління підприсмством. Здійснено систематизацію маркетингових стратегій антикризового управління та визначено умови їх застосування в системі менеджменту підприємства. Узагальнено результати досліджень з антикризового управління та досвід використання маркетингових інструментів у реалізаиії антикризових програм і на иій основі запропоновано етапи розробки маркетингової стратегї антикризового управління
\end{abstract}

Ключові слова: антикризове управління, криза, маркетинг, системний підхід, антикризова програма, стратегія 


\title{
МАРКЕТИНГОВЫЕ СТРАТЕГИИ В АНТИКРИЗИСНОМ УПРАВЛЕНИИ ПРЕДПРИЯТИЕМ
}

\author{
Терещенко Д.А., к.гос.упр., доцент, \\ Титова Н.А., студентка (ХНУСА)
}

\begin{abstract}
В статье исследуется современная проблематика маркетинга как философии, стратегии и тактики антикризисного управления предприятием. Проведена систематизация маркетинговых стратегий антикризисного управления и определены условия их применения 6 системе менеджмента предприятия. Обобщены результаты исследований по антикризисному управлению и опыт применения маркетинговых инструментов в реализации антикризисных программ и на этой основе предложены этапы разработки маркетинговой стратегии антикризисного управления
\end{abstract}

Ключевые слова: антикризисное управление, кризис, маркетинг, системный подход, антикризисная программа, стратегия

\section{MARKETING STRATEGIES IN THE ANTICRISIS MANAGEMENT OF THE ENTERPRISE}

\section{Tereshchenko D. A, PhD in Public Administration, Associate Professor, Titova N.A., student (Kharkov National University of Construction and Architecture)}

The article investigates the problems of modern marketing as a philosophy, strategy and tactics of anti-crisis management. The systematization of the marketing strategies of crisis management and their application in the management of the enterprise. The results of studies on crisis management and experience of marketing tools in the implementation of anti-crisis programs, and on this basis to define the stages of developing a marketing strategy of crisis management.

It is concluded that marketing management, including marketing strategies play a key role in the crisis management of the enterprise. First, marketing management provides guiding methodological principles - marketing concept, which provides orientation strategy on customers needs. Second, marketing provides initial data for the development of a strategic plan for the company, helping to identify attractive market opportunities and assess the potential of allowing organizations. Third, within each unit of the enterprise marketing management helps to make effective management decisions in order to prevent crises in the organization.

Keywords: anti-crisis management, crisis, marketing, systemic approach, anti-crisis program, strategy

\begin{tabular}{|c|c|}
\hline $\begin{array}{rrrr} & \text { Постановка } & \text { проблеми. } & \text { Головною } \\
\text { стою } & \text { діяльності } & \text { сучасних } & \text { суб'єктів }\end{array}$ & $\begin{array}{l}\text { маркетингових принципів, методів } \\
\text { стратегій антикризового управління. }\end{array}$ \\
\hline силег & 13 \\
\hline инку у стр & мам \\
\hline ягнення & етратегій \\
\hline сукупності & $\mathrm{y}^{1}$ \\
\hline ктичних цілей, & них та $3 c^{2}$ \\
\hline зивають такі: зростання обсягів & дров [1], В.ІІ. \\
\hline Іня частки & В.О. Василенко [3], Н. Д. Гетм \\
\hline x і потенційних спож & А.В.Камнєва \\
\hline 25$]$ & Е.М. Коротков [2], О.В. Короткова [7], Ю. \\
\hline ово-еконс & Тельник \\
\hline детермінована & Ткешелашвілі [11], 3.С. Шершньова [10], J \\
\hline іідприємстві & та \\
\hline равління & алы \\
\hline узгодЖеност1 & ОВИХ \\
\hline
\end{tabular}

Вісник економіки транспорту і промисловості № 51, 2015 
попередження або подолання кризових ситуацій в господарській діяльності підприємства.

Постановка завдання. Метою статті є обгрунтування доцільності використання маркетингових стратегій в антикризовому управлінні підприємством в умовах нестабільної економічної ситуації в Україні та світі; розробка рекомендацій щодо застосування концепції маркетингового управління у реалізації антикризових програм розвитку підприємства.

Виклад основного матеріалу дослідження. Стратегія підприємства, як відомо, - це комплексний план досягнення місії організації, а стратегія управління являє собою господарську політику, розроблену на основі передбачення майбутнього розвитку, характеру i наслідків виробничогосподарської діяльності шляхом визначення і прогнозування результатів, потрібних ресурсів, засобів і методів менеджменту [1; 3].

Під антикризовим управлінням розуміється система стратегічних заходів, спрямованих на попередження кризової ситуаціï, а в разі іi виникнення - система заходів щодо виходу 3 кризи 3 урахуванням всіх наявних можливостей 3 мінімальними втратами i досягненням позитивного результату в майбутньому [7, с. 8].

У сучасній економіці антикризова стратегія відіграє визначну роль в забезпеченні довгострокового функціонування і ефективної діяльності підприємства в конкурентному середовищі. Антикризова стратегія $є$ засобом управління змінами i спрямована на пошук альтернативних рішень щодо виходу підприємства 3 кризового стану [1].

Антикризова стратегія формується в межах загального стратегічного планування, але особливістю $є$ акцептування уваги на засобах оцінки, аналізу i контролю, визначення завдань, розроблення та реалізації управлінських рішень, які стосуються основних параметрів життєдіяльності підприємства у кризовій ситуації [9, с. 216].

3 усіх стратегій основних підсистем організації виділяється одна ключова стратегія (маркетингова), за допомогою якої задається й істотно детермінується весь процес розробки інших приватних стратегій організації, а також іiі корпоративної стратегії в цілому. Таку логіку побудови стратегії можна назвати логікою первинного виділення ведучої ключової стратегїі-підсистеми 3 наступною похідною побудовою на їі основі всіх інших стратегій-підсистем, а також корпоративної стратегії як системи в цілому. Стратегія в маркетингу - більш стійкий інструмент, ніж мета, тому що служить умовою, що забезпечує реалізацію цілей і місії організації [1-4; 8; 10]. Частка маркетингової стратегіï в загальній стратегії підприємства становить близько 80 \% [6, с. 11]. При цьому маркетинг у антикризовому управлінні застосовується на різних стадіях циклу: у передкризовий, кризовий та після кризовий період, оскільки всі ці стадії є об’єктом антикризового управління [2; 3].

Концепція маркетингу полягає в тому, що планування і координація всієї діяльності підприємства грунтується на реалізації основної цілі - задоволення потреб споживача. Маркетингові рекомендації розглядаються як базова інформація до ухвалення антикризових управлінських рішень, спрямованих на стабілізацію і вихід підприємства 3 кризи.

Зазначимо, що антикризове управління складається 3 двох аспектів: активного та пасивного. Завдання маркетингу в межах пасивного антикризового управління передбачає всебічне дослідження та оцінку зовнішнього середовища підприємства 3 метою завчасного виявлення причин виникнення кризових ситуацій або додаткових можливостей. $\mathrm{y}$ контексті активного антикризового управління перед маркетингом висувають завдання 3 оперативного збирання інформації відносно об'єктів зовнішнього середовища, пов'язаних iз виникнення кризи на підприємстві [5, с. 24].

На нашу думку, антикризова стратегія, має бути спрямована на встановлення параметрів, що визначають широкий спектр альтернативних дій 3 вирішення протиріч, неузгодженості між цілями підприємства, наявними ресурсами та впливом зовнішнього та внутрішнього середовищ.

Як зазначає Є.М. Коротков, при виборі маркетингової стратегії істотну допомогу менеджеру може надати виділення ознак та класифікація стратегій відповідно до вказаних ознак [2] : 1) стосовно маркетингового середовища (інтеграційні стратегіï: 
макроекономічна; зовнішньоекономічна; регіональна; виробничої і невиробничої сфери; міжгалузева і галузева); 2) за функиіональним призначенням (стратегії факторів виробництва: виробничих; інвестиційних; інноваційних; фінансових; трудових й інформаційних); 3) щодо розвитку організації (антикризова стратегія: запобігання неплатоспроможності, вихід із кризи, ліквідація іiі наслідків); 4) щодо виду $i$ масштабу ринку (ринкові стратегії розширення ринку, проникнення у межах ринку, диверсифікаціі); 5) стосовно пріоритетів засобів маркетингу (товарна стратегія щодо асортименту, рівня якості, товарної марки, рівня сервісу; цінова стратегія щодо рівня цін, єдиних та перемінних цін; збутова стратегія щодо довжини та ширини каналу розподілу, складування та транспортування товарів; комунікативні стратегії інформування про переваги товару, переконання, мотивації, нагадування; 6) відповідно до ринкової кон 'юнктури (стратегія попиту та пропозиції: стимулююча, креативна, що підтримує, протидіюча, синхронізуюча); 7) відповідно до ринкової поведінки (стратегія дрібних організацій: копіювання продуктів ведучих фірм, пристосування до потреб, інтеграція 3 більш великими організаціями; стратегія середніх організацій: патентна, ринкових ніш, інноваційна, інтенсивного маркетингу; стратегія великих фірм: глибокого проникнення, “зняття вершків”).

Маркетингові стратегії антикризового управління також класифікують за стадією (етапом) антикризового управління; залежно від характеру впливу кризи на діяльність підприємства.

За стадією (етапом) антикризового управління виділяють такі маркетингові стратегії [8]: 1) передкризове управління стратегії, які запобігають кризовим ситуаціям («позиційний захист»; «фланговий захист»; «мобільний захист»); 2) кризове управління стратегії, які згладжують дію кризових явищ, активізують вихід 3 кризи (стратегія «відступу», стратегії диверсифікації, малобюджетні стратегії за комплексом маркетингу); 3) післякризове управління стратегії, спрямовані на ліквідацію наслідків кризи, пошук нових ринкових можливостей (стратегія розвитку ринку; стратегія розвитку товару; стратегія глибокого проникнення на ринок).
Залежно від характеру впливу кризи на діяльність підприємства розрізняють [10]:

- стратегії «скорочення» (стратегія «замороження»; стратегія оптимізації витрат);

- стратегії «захоплення ринку» (стратегіï диверсифікації; стратегія «регіональної експансії», стратегія прямої інтеграції - об'єднання зусиль виробника i посередників - відкриття оптових баз, фірмових магазинів; «партнерські фірми» створення офіційних представництв; «роз'їзні бригади» - основна задача таких бригад укладання договорів 3 оптовиками, формування мережі збуту; власне торгове представництво - відкриття власного представництва в іншому регіоні; побудова дистрибуційної мережі).

Слід зазначити, що універсальної маркетингової стратегії не існує.

Кожне підприємство визначає, яка зі стратегій $\epsilon$ для нього найкращою 3 огляду на свою позицію в галузі, а також на свої цілі, можливості й ресурси. Також в умовах кризи необхідна комплексна взаємодія інструментів маркетингу та менеджменту на підприємстві. Якщо метою управління організацією $\epsilon$ прийняття ефективних рішень, то метою маркетингу як філософії ведення бізнесу формування рішень, адекватних зовнішнім умовам, що особливо важливо під час негативного впливу кризових явищ.

Головна особливість маркетингових стратегій антикризового управління - здатність швидко адаптуватися під мінливе середовище i створювати перспективні підприємницькі можливості для стабілізації економічного становища підприємства або покращення ринкових позицій (зростання ринкової частки, обсягу продажів, зростання лояльності клієнтів та ін.). Для забезпечення ефективної реалізації маркетингової стратегії антикризового управління на підприємстві необхідним та важливим $\epsilon$ обгрунтування процесу іiі формування. Проаналізувавши різні методичні підходи щодо формування антикризової стратегіï на підприємстві, зокрема маркетингової [1-3; 5-10] ми прийшли до висновку, що процес розробки маркетингової стратегії в антикризовому управлінні повинен бути представлений як динамічна сукупність таких основних взаємозалежних управлінських процесів (рис. 1). 
Діагностика кризових явищ і загрози банкрутства підприємства (комплексний аналіз результатів виробничо-господарської діяльності та фінансово-майнового становища підприємства, вивчення динаміки найважливіших обсягових та якісних показників діяльності тощо)

Аудит зовнішнього і внутрішнього середовища підприємства, оцінка потенціалу ринку і стійкості підприємства на ринку

Визначення мети і завдань антикризового управління, розробка стратегічних цілей маркетингу і альтернативних варіантів стратегії маркетингу

Визначення суб’єкта антикризової маркетингової діяльності, зокрема створення і регламентація діяльності антикризової робочої групи

Оцінка ресурсного потенціалу антикризового маркетингового управління

Генерування та порівняльний аналіз альтернативних маркетингових стратегій

Оцінка ризиків реалізації альтернативних маркетингових стратегій антикризового

Вибір та узгодження маркетингової стратегії антикризового управління; коригування стратегічних і тактичних цілей розвитку підприємства

Розробка плану (програми) антикризових маркетингових заходів (довгострокових, середньострокових, короткострокових);

\begin{tabular}{|c|}
\hline $\begin{array}{c}\text { Аналіз і реінжиніринг ключових бізнес-процесів, що впливають на ефективність } \\
\text { реалізації маркетингової стратегії антикризового управління }\end{array}$ \\
\hline $\begin{array}{c}\text { Визначення основних інструментів реалізації антикризової стратегії та термінів } \\
\text { реалізації; розробка системи індикаторів оцінки реалізації стратегії }\end{array}$ \\
\hline $\begin{array}{c}\text { Реалізація стратегії антикризового маркетингового управління, моніторинг ефективності } \\
\text { реалізації антикризової стратегії; контроль та оцінка антикризової маркетингової } \\
\text { стратегії }\end{array}$ \\
\hline
\end{tabular}

Рис.1. Основні етапи розробки і реалізаиії маркетингової стратегії антикризового управління

Вісник економіки транспорту і промисловості № 51, 2015 
У ході реалізації маркетингової стратегії антикризового управління необхідно постійно здійснювати контроль за ії виконанням i, за необхідності, вносити корективи. На підприємстві повинна існувати система моніторингу за змінами, що спрямована на виявлення не лише позитивних результатів від впровадження маркетингової антикризової стратегії, а також і на виявлення негативних чинників.

Щоб показати роль маркетингового управління в діяльності будь-якої організації, такі західні фахівці як Й. Уілсон, Е. Чанга, проводять таку аналогію з будовою людського тіла: “Якщо дослідження й розробки уявити людським мозком, технологічне виробництво хребтом, а збут - тілом людини, то тоді маркетинг і маркетинговий менеджмент можна порівняти 3 вітамінами або гормонами, які проходять через усі ці ділянки, впливаючи на них і живлячи їх енергією" [4, с. 78].

Отже, враховуюче вищесказане, можна стверджувати, що антикризове управління на основі маркетингової стратегії передбачає іiі реалізацію в усіх функціональних підсистемах підприємства (операційній, фінансовій, кадровій, інформаційно-комунікативній та ін.) та реінжиніринг ключових бізнес-процесів підприємства на засадах маркетингового менеджменту. Маркетингове управління, зокрема маркетингові стратегії грають ключову роль в процесі антикризового управління діяльністю підприємства. Поперше, маркетингове управління забезпечує керівні методологічні принципи маркетингову концепцію, яка передбачає орієнтацію стратегії підприємства на потреби споживачів. По-друге, маркетинг надає початкові дані для розробки стратегічного плану підприємства, допомагаючи виявити привабливі можливості ринку і дозволяючи оцінити потенціал організації. По-третє, в рамках кожного окремого підрозділу підприємства маркетинг допомагає розробляти ефективні управлінські рішення щодо попередження кризи.

Методологічною базою впровадження маркетингової стратегії антикризового управління $є$ такі підходи: 1) системний розгляд процесів антикризового управління як систем, тобто поєднання в одне ціле елементів, необхідних для досягнення певної мети; 2) комплексний - єдність організаційних, економічних, соціальних, правових, психологічних та інших аспектів менеджменту; 3) оптимізаційний - потребує спочатку кількісного визначення параметрів маркетингового антикризового управління, а потім розробку математичних моделей оптимізації; 4)ситуаційний - дії підприємства та іiі керівника мають залежати від поточного стану внутрішнього і зовнішнього середовища підприємства.

Висновки даного дослідження $i$ перспективи подальших робіт у цьому напрямку. Проведене дослідження дає можливість стверджувати, що в сучасних умовах підвищеної невизначеності та ризику маркетинг має бути не просто однією 3 підсистем діяльності підприємства, а фундаментом, на якому грунтується робота усіх інших його підрозділів. Тому керівникам вітчизняних підприємств особливу увагу слід приділяти розробці ефективної маркетингової стратегії антикризового управління, яка враховуватиме специфіку функціонування та зовнішнього середовища конкретного підприємства i сприятиме виходу підприємства із кризового становища. Таке ставлення до впровадження антикризового управління надасть можливість не лише приймати найменш ризиковані управлінські рішення, які дозволять досягти поставленої мети i результату 3 мінімумом додаткових засобів і за мінімальних негативних наслідків, але й сприятиме досягненню цілей підприємства, покращенню його іміджу, підвищенню лояльності споживачів i зміцненню його конкурентних позицій.

Таким чином, роль маркетингу в антикризовому управлінні підприємством $\epsilon$ провідною. Проте внесення у сучасних умовах господарювання відповідних змін у маркетингову діяльність підприємств вимагає дослідження іiі ефективності, що повинно стати предметом подальших досліджень.

\section{СПИСОК ЛІТЕРАТУРИ}

1 Александров Г. А. Антикризисное управление : теория, практика, инфраструктура / Г. А. Александров; отв. ред. Г. А. Александров. - М.: БЕК, 2007. - 544 с.

2 Антикризисное управление: 
учебник/ под. ред. Э.М. Короткова. - М. : ИНФРА-М, 2001. - 432 с.

3 Василенко В.О. Антикризове управління підприємством : навч. посібник / В.О. Василенко. - К. : ЦУЛ, 2003. - 504 с.

4 Ілляшенко С. М. Маркетинг для магістрів: Навч. посібник. - Суми: Університетська книга, 2007. - 928 с.

5 Камнєва А.В. Дослідження існуючих інструментів та моделей антикризового управління на підприємстві / А.В.Камнєва // Економіка та управління підприємствами машинобудівної галузі: проблеми теорії та практики, 2014, № 4 (28). C. $15-27$.

6 Ковалева С. Маркетинговые затраты и маркетинговые инвестиции / С. Ковалева // Человек и труд. -2010 . - № 4. - С. $59-60$

7 Короткова О.В. Деякі аспекти реалізації антикризового управління в сучасних економічних умовах / O.В. Короткова, Н.В. Єгорова // Економіка та держава. - 2011. - № 5. - С.7-9.
8 Мельник Ю.М. Маркетингові інструменти антикризового управління підприємством / Ю.М. Мельник // Маркетинг. Менеджмент. Інновації : монографія / за ред. д.е.н., професора С.М. Ілляшенка. - Суми : ТОВ «Друкарський дім «Папірус», 2010. - С. 505-516.

9 Телін С.В. Антикризове управління як засіб запобігання банкрутству підприємств // Вісник ХНУ. -2010. - № 5. Економічні науки. - Том 2 - С.216.

10 Шершньова 3.€. Антикризове управління підприємством : навч. посіб. / 3.Є. Шершньова, В. М. Багацький, Н. Д. Гетманцева; за заг. ред. 3. Є. Шершньової. К. : KHEУ, 2007. $-680 \mathrm{c}$.

11 Шульгіна Л.М., Ткешелашвілі, М.Л. Маркетингове управління туристичними підприємствами : монографія / Л.М. Шульгіна, М.Л. Ткешелашвілі; Нац. техн. ун-т України «КПІ», Київ. нац. торг.-екон. ун-т, Європейський ун-т. - Київ-Тернопіль : Астон, 2011. - $296 \mathrm{c}$.

Рецензент д.е.н., професор ХНУБА Чупир О.М. Експерт редакційної колегії к.е.н., дочент УкрДУЗТ Полякова О.М. 